\title{
観光地におけるイメージ形成と資源保全プロセスに関する比較研究 COMPARISON STUDY ON PROCESS OF FORMING BRAND IMAGE AND PRESERVATION OF REGIONAL RESOURCES IN TOURIST AREAS
}

\author{
丸上雄哉*, 出口敦** \\ Yuya MARUGAMI and Atsushi DEGUCHI
}

\begin{abstract}
Tourism is expected to vitalize the declined region's economy and to create the region's brand, but it sometimes causes the problems such as the pollution and the disruption of natural resources. This study aims to clarify the treating process of the problems caused by the tourism boom through case studies and to suggest the process for sustainable development of tourism areas based on analysis on the solution measures in each of the cases. As a conclusion, it suggests the importance that the local society of tourist areas should consider the process including the recycling use of regional resources together with the promotion for sight-seeing in order to make the balance of vitalization of tourism and preservation of natural resources.
\end{abstract}

Keywords : Tourism, Image banding, Regional resource, Environmental measure, Trade-off 観光，ブランディング，地域資源，環境施策，トレードオフ

\section{1. はじめに}

\section{1-1 研究の背景}

少子高齢·人口減少社会を迎えた日本において,観光は地域経済を 活性化し, 街に対する誇りや愛着を涵養する手段として注目されて いる. 観光白書 ${ }^{1)}$ によれば，2008 年度における国内旅行消費額は 23.6 兆円, 生産波及効果は 51.6 兆円 (国内生産額の $5.3 \%$ ) であり, 雇用誘発効果も含め, 日本経済に与える影響は大きい. 現在, 日本 ではビジット・ジャパン・キャンペーンの展開や, 中国人の個人向け 観光ビザの解禁等, 観光立国に向けた動きが活発になっている.

本稿では, 固有の観光資源を持ち, 当該資源に依存しながら積極 的な観光客誘致を行う地域を「観光地」と定義する. 観光地として より多くの観光客を誘致するためには, 日本らしさや個性となる地 域資源を活用し, イメージの形成·強化や知名度の向上 (以下, 総称 して「ブランディング」と呼ぶ）を進める必要がある. しかしなが ら, 観光資源が各観光地において持続可能な方法で利用されている とは限らない, 例えば, 鹿児島県屋久島町では, 世界遺産登録を契 機に観光地としてのブランドが向上し, 観光客が急増したことによ り, 島内経済は潤ったが, 登山道におけるし尿問題や植生の踏み荒 らし問題が生じた. 観光振興と資源の保全がトレードオフの関係に 置かれた典型例である。こうした問題は, 観光立国を目指す動きの 中で, 今後さらに増加するものと推測される.

\section{1-2 研究の目的と方法}

観光振興の過程で生じる問題への対応は, 対症療法的になること が多く, 観光振興と資源の保全はトレードオフの関係, もしくは切 り離して捉えられ, 多くの観光地で未だにその両立の方策を描けず
にいる，そこで，本研究では，地域特性を活かした魅力と持続性を 兼備する観光地形成に向けた観光計画立案を支援するために, 資源 や環境の保全も内包した観光地ブランディングの方法のモデル構築 を目指し, 以下の 3 点を具体の目的として, 特に前項で定義した観 光地で生じ易い問題について, 予防·回避·回復手法の整理を行った.

（1）資源的危機に直面した観光地の変容事例を整理し，各観光地に おける問題と対応策およびその結果を整理する.

(2) 観光地のブランディングと資源保全プロセスの整理, 構造化を 通じ, 両者の相互関係と環境問題の発生や資源破壞等に至る過 程を明らかにする.

(3) 観光地のブランドとなる施策を整理し, 施策の現状と問題点を 鑑み，持続可能なブランディングの方法のモデルを提示する.

研究の遂行にあたっては, 個々の調查対象地で, 実地調查, ヒア リング, 資料·文献調查により情報収集を行った。 また, 観光地の盛 衰状況注 1) とその背景となった出来事・施策·活動を照らし合わせ, 観 光地のブランドを動かす要因を把握した.

\section{1-3 既往の研究}

観光の弊害を扱う研究として, 70 年代後半にホスト\&ゲスト論 ${ }^{2)}$ が展開され, 観光に伴う文化的真正性の欠如等の問題が提起された. 90 年代には観光開発の側面からの課題と対策の議論が活発となり, 2000 年頃からは観光振興とまちづくりの概念を組み合わせた「観光 まちづくり」3)の概念が導入され, 以降, 持続可能な観光まちづく りに係る研究や, 観光地のブランディングに係る研究が展開された. 前者については, 地域主導で持続的な観光を創り出す「自律的観

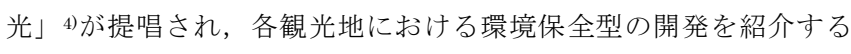

\footnotetext{
$*$ 三井不動産(株) 修士 (環境学)

Mitsui Fudosan Co., Ltd., M. Env.

** 東京大学大学院新領域創成科学研究科 教授. 工博

Prof., Graduate School of Frontier Sciences, The Univ. of Tokyo, Dr. Eng.
} 
研究 5)6), 観光資源の創出·活用·保全に関して事例を挙げつつ知見を 整理している研究 7)8, 資源の持続的な利用手段としてエコツーリズ ムを紹介・分析した研究 9110)が見られ, 個別の観光開発に対して持続 可能性を付与寸る手法が整理されている. 一方, 後者については, 世界遺産登録に伴う観光地の変容と環境的危機を整理するとともに 制度的問題について考察した研究 1112), 観光地のイメージ形成に至 る歴史的背景及びメディアの介在についてまとめた研究 ${ }^{13)}$, 観光地 のブランディングの種類を比較. 分類した研究 ${ }^{14)}$ )等が挙げられ, 観 光地のブランディングに向けた施策の導入事例の集積や, 観光地が イメージを構筑するプロセスと要素の解明·分類が進んでいる.

しかしながら, 観光地における資源問題とブランディングは個別 に整理される傾向にあり, 観光資源が問題や危機に至る過程と, 観 光地のブランディング及びその他社会的事象との相互関係に言及す る研究は殆ど見られない. また, 全般に単独の観光地に着目する研 究が多く, 複数事例を比較する研究は少ない. 各観光地で生じる問 題と対策は事例毎に整理されているが，観光地のブランディング過 程における資源的問題の発生を前提として捉え, 一般化した対策を 明示寸る研究は見られなかった. 以上を踏まえ, 観光地のブランデ イングについて, その過程で生じる種々の問題や社会的事象との相 互関係を含めて時系列に整理し, 複数事例の比較の中で一般化した 対策を明示する点を本研究の特色とする.

\section{2. 観光地におけるブランド施策の現状と研究対象の選定 2-1 観光地における環境施策}

日本の観光地における環境施策について表 1 に整理した。これら の施策は, 環境保全効果を有すると共に, 観光振興効果や地域や資 源のブランディング効果を併せ持つが，このうち，国あるいは国際 的な環境施策の指定·認定（以下，「冠ブランド」と呼ぶ）は，資源 の価值の裏付けを得ることに等しいと考えられ, 資源と観光地の価 值向上に活用され，観光客誘致の手段となっていると言える.

\section{2-2 観光地における冠ブランド施策の現状}

冠ブランドとなる施策は, 1934 年の国立公園指定を皮切りに, 各 種文化財等, 保護対象を拡張してきた. 80 年代からは, 国際機関に よる指定(世界遺産登録等)が開始された。冠ブランドは年代によっ て種類を変化させつつも, 現在は乱立傾向にある(図 1). 背景には, ブランド向上効果に着目した行政が，指定や登録を行うパッケージ を意図的に増設していることや，国際的機関による環境施策の認定 のために, 国の保護施策が条件となっていることが挙げられる.

\section{2-3 研究対象の選定}

『事典・日本の観光資源』 ${ }^{15)}$ に記載された資源を持つ観光地のう ち, 次の 3 点を基準に, 資源や問題の種類の重複を避けて選定した.

(1) 環境施策の適用に至るプロセスやその効果を観察するため, 冠 ブランドの指定もしくは指定に向けた活動実績があること

(2) 観光資源と人間活動の相互関係を観察するため, 開発・利用· 保全等，人間が観光資源に対して影響を与えたこと

(3) 問題の発生や解決に至るプロセスを観察するため, 環境·社会 問題を内包した観光地であること

以上の基準より, 白骨温泉, 柳川, 二セコ山系, 伊香保温泉, 摩 周湖, 尾瀬, 足尾銅山, 鳥取砂丘, 琴引浜, 屋久島を選定した.

なお，同じ観光地内においても複数の資源が存在し，それらが総
表 1 観光地における環境施策

\begin{tabular}{|c|c|c|}
\hline 拄定 & 施策 & 観光地に適用する場合に観察される課題・問題点 \\
\hline \multirow{3}{*}{$\begin{array}{l}\text { 国 } \\
\text { 際 } \\
\text { 機 } \\
\text { 関 }\end{array}$} & 世界遺産条約 & 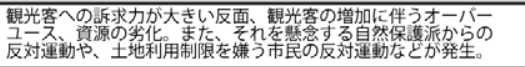 \\
\hline & ラムサール条約 & 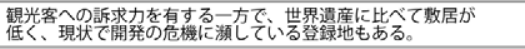 \\
\hline & $\begin{array}{l}\text { 世界ジオパーク } \\
\text { 登録 }\end{array}$ & 新しい事業であることから現状では観光客の認知度が低い。 \\
\hline \multirow{4}{*}{ 国 } & $\begin{array}{l}\text { 自然保護法 } \\
\text { (国立公㯖指定) }\end{array}$ & 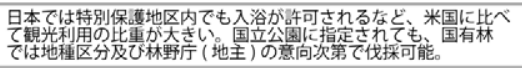 \\
\hline & 文化財保護法 & 形䯓化。高齢化（重要伝統的建造物群保存地区)。 \\
\hline & $\begin{array}{l}\text { 保護林指定 } \\
\text { (森林生態系保㜔地域指定) }\end{array}$ & 国有林野事業の財政難に伴う国有林売却の懸念。 \\
\hline & $\begin{array}{l}\text { (原生)䚁然環定 } \\
\text { 境保全地域指定 }\end{array}$ & 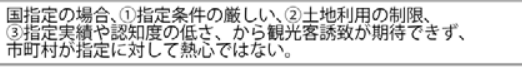 \\
\hline \multirow{11}{*}{$\begin{array}{l}\text { 地 } \\
\text { 放 } \\
\text { 堡 }\end{array}$} & 都市計画・憲章・構想 & 策定する自治体の方針次第で観光振興に偏ることがある。 \\
\hline & $\begin{array}{l}\text { 立入・車・経路 } \\
\text { ·資源使用規制 }\end{array}$ & 市民や所有者の経済・管理・生活的負担の増加。 \\
\hline & 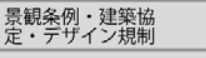 & 市民や所有者の経済・管理・生活的負担の増加。 \\
\hline & エコ施設整備 & 設置・維持の費用增加。 \\
\hline & 募金・協力金 & 観光客の負担増加。割高感。 \\
\hline & $\begin{array}{l}\text { 植载·清掃 } \\
\text { ·環境改善活動 }\end{array}$ & 設置・維持の費用增加。 \\
\hline & 植林・記念植樹 & 設置・維持の費用增加。 \\
\hline & 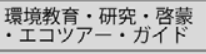 & ガイドとのトラブルの発生。ガイドの質の確保。 \\
\hline & $\begin{array}{l}\text { 市氐団体・NPO } \\
\text { ·財団の結成や連携 } \\
\end{array}$ & 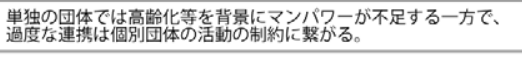 \\
\hline & CSR 活動 & 低利益の企業では CSR 活動が進んでいない。 \\
\hline & 特区・特例 & 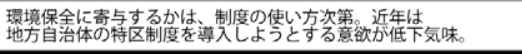 \\
\hline
\end{tabular}

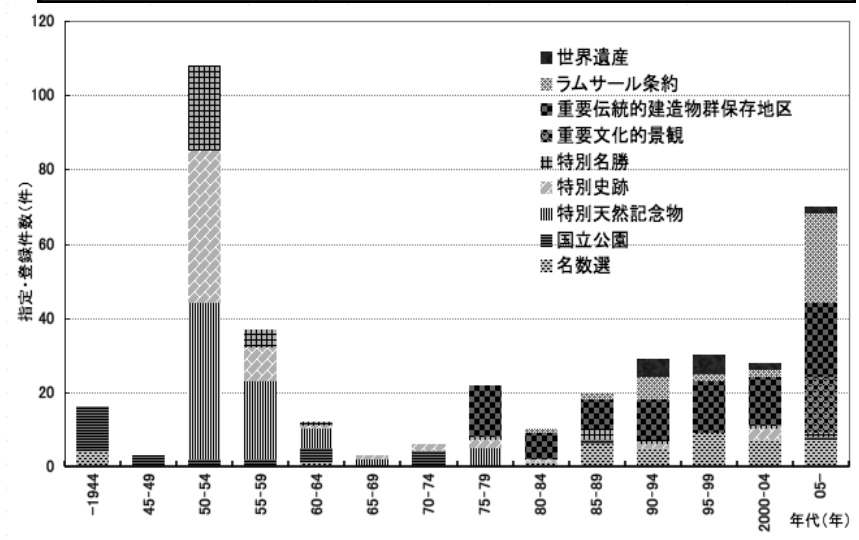

図 1 観光地におけるブランディング施策適用数の変遷注 2$)$

合されてブランドを形成するが，観光地内の資源の種類や数量を正 確に把握することが困難であるため，本稿では当該観光地のシンボ ルとして機能する特定の資源に着目し，分析を行うこととした．

\section{3. ケーススタディ}

\section{3-1 研究対象の概要}

研究対象として選定·分析した観光地について, 着目した資源, 経 験したイメージ認知·強化の契機, 資源の危機·問題, 主な対策・対応, その他を表 2 にまとめた ${ }^{16)}$-26). 本稿ではその内, 温泉観光地とし て白骨温泉, 森林等の自然資源を有する観光地として屋久島を取り 上げ，事例分析の詳細を示すこととする。

\section{3-2 白骨温泉}

\section{（1）白骨温泉の概要と調査方法}

白骨温泉 (長野県松本市) は山岳に囲まれ，湯川の流水音が響く温 泉観光地である. 集落は温泉宿が 10 軒, 日帰り入浴施設が 2 軒, 土 産屋·塟麦屋·案内所が各 1 軒, 及び空き屋や物置で構成され，民家 はなく交通アクセスも悪い。こうした立地構成上に希少な炭酸水素 
表 2 研究対象とした観光地と着目要素

\begin{tabular}{|c|c|c|c|c|c|c|}
\hline \multicolumn{2}{|c|}{$\begin{array}{l}\text { 着目 } \\
\text { 資源 } \\
\end{array}$} & 観光地名 & イメージ認知・強化の契機 & 資源の危機・問題 & $\begin{array}{c}\text { 主な対策・対応 } \\
\text { (問題発生前からの取組みも含む) } \\
\end{array}$ & $\begin{array}{c}\text { 観光客推移の形 / 最盛年 } \\
\text { 現在の状況 / その他 } \\
\end{array}$ \\
\hline \multirow{2}{*}{ 温 } & $\begin{array}{l}\text { 泉 } \\
\text { 斦 }\end{array}$ & 白骨温泉 & $\begin{array}{l}\cdot \text { 秘湯ブーム (朝日新聞) } \\
\cdot \text { 温泉のイメージ悪化 }\end{array}$ & $\begin{array}{l}\cdot \text { 白濁温泉の枯渴 } \\
\cdot \text { 温水のイメージ悪化 }\end{array}$ & $\begin{array}{l}\cdot \text { 内湯巡り } \\
\cdot \text { 温泉表認定制度 }\end{array}$ & $\begin{array}{l}\cdot \text { 山型 } / 2000 \text { 年 } \\
\cdot \text { 転換・過渡期 }\end{array}$ \\
\hline & $\begin{array}{l}\text { 町 } \\
\text { 並 }\end{array}$ & 伊香保温泉 & $\begin{array}{l}\text { ·温泉都市計画 ( 石段街の形成 ) } \\
\text { ·石段の延伸 } \\
\text { ・黄金の湯」・「宝の湯」 }\end{array}$ & $\begin{array}{l}\cdot \text { 温泉使用の利権問題 } \\
\cdot \text { 低価值 / 循環湯の } \\
\quad \text { 「天然温泉」表示 } \\
\end{array}$ & $\begin{array}{l}\cdot \text { 白銀の湯の発見と利用 } \\
\text { ※黄軎の湯に比べて低価値 } \\
\text { ·証明書の発行 }\end{array}$ & $\begin{array}{l}\text { · 山型 } / 1991 \text { 年 } \\
\text { ·転換・過渡期 }\end{array}$ \\
\hline \multirow{2}{*}{ 文 } & 教 & 足尾銅山 & ·足尾銅山鉱毒事件 & $\begin{array}{l}\text { ·鉱毒のイメージ } \\
\text { ・リピーター獾得の失敗と } \\
\text { 観光客の継続的減少 }\end{array}$ & $\begin{array}{l}\cdot \text { 環境教育施設の設置 } \\
\cdot \text { 世界遺産登録の模索 } \\
\text { ·史跡指定 / 名数選等 }\end{array}$ & $\begin{array}{l}\text { ·衰退持続型 / } 1984 \text { 年 } \\
\text { ·衰退期 / 足尾銅山観光 } \\
\text { は1980 年にオープン }\end{array}$ \\
\hline & 歴 & 柳川 & $\begin{array}{l}\cdot \text { 映画「からたちの花」 } \\
\cdot \text { 北原白秋「大柳川都市計画論」 } \\
\cdot \text { 映画「柳川堀割物語」 }\end{array}$ & $\begin{array}{l}\cdot \text { 堀割の水質悪化 } \\
\cdot \text { 堀割埋立て計画 }\end{array}$ & $\begin{array}{l}\cdot \text { 水路美化/清掃活動 } \\
\cdot \text { 市職員による啓蒙活動 }\end{array}$ & $\begin{array}{l}\cdot \text { 増加継続型 /2004 年 } \\
\text { 繁栄期 }\end{array}$ \\
\hline \multirow{2}{*}{ 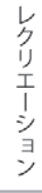 } & $\begin{array}{l}\text { ス } \\
\text { F } \\
\text { I }\end{array}$ & ニセコ山系 & $\begin{array}{l}\cdot \text { ·豪州でのネットロコミ } \\
\text { ·外国人観光客の急增 } \\
\text { ·地価上昇率日本一 }\end{array}$ & · 乱開発 & $\begin{array}{l}\cdot \text { ·準都市計画区域の設定 } \\
\cdot \text { 大規模リジート開発 } \\
\text { · 母国によるケア }\end{array}$ & $\begin{array}{l}\text { ·増加継続型 (内訳変化 ) } \\
\text { /1990 年 } \\
\cdot \text { 成長期 }\end{array}$ \\
\hline & $\begin{array}{l}\text { 海 } \\
\text { 水 } \\
\text { 浴 }\end{array}$ & 琴引浜 & $\begin{array}{l}\cdot \text { 三輪茂雄氏の訪問 } \\
\cdot \text { 町や国の文化財指定/名数選 } \\
\cdot \text { 事故や保護活動のメディア報道 }\end{array}$ & 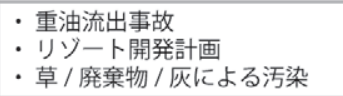 & $\begin{array}{l}\cdot \text { 鳴き砂を守る会の活動 } \\
\cdot \text { 禁煙ビ二チ化 } \\
\text { · 名勝 / 天然記念物指定 }\end{array}$ & $\begin{array}{l}\cdot \text { 複数山型 /1990 年 } \\
\cdot \text { 衰退期 } \\
\text { ※近年は衰退傾向が続く }\end{array}$ \\
\hline \multirow{4}{*}{ 筫 } & 砂 & 鳥取砂丘 & $\begin{array}{l}\text { ·砂丘保存運動 } \\
\text { 天然記念物 / 国立公園指定 }\end{array}$ & $\begin{array}{l}\text { ·農業利用 / 砂防目的の植林 } \\
\text { 雑草繁茂と煩雑な除草手続き } \\
\text { 上上記に伴う砂停滞・景観変化 }\end{array}$ & $\begin{array}{l}\cdot \text { 天然記念物 / 国立公園指定 } \\
\cdot \text { 保安林解除 / 伐採 } \\
\cdot \text { 除草作業 }\end{array}$ & $\begin{array}{l}\cdot \text { 複数山型/1972 年 } \\
\cdot \text { 転換・過渡期 }\end{array}$ \\
\hline & $\begin{array}{l}\text { 湿 } \\
\text { 地 }\end{array}$ & 尾瀬 & $\begin{array}{l}\dot{N} \cdot \text { NHKラジオ「夏の思い出」 } \\
\cdot \text { 木道敷設 } \\
\text { 自然保謢運動の発祥/CSR }\end{array}$ & $\begin{array}{l}\text { ·水力発電ダム計画 } \\
\cdot \text { 道路建設問題 } \\
\cdot \text { ブームに伴う裸地化 }\end{array}$ & 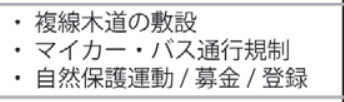 & $\begin{array}{l}\cdot \text { 複数山型 } \\
\cdot \text { 成長期 } \\
\text { ※2009 年は減少 }\end{array}$ \\
\hline & 湖 & 摩周湖 & $\begin{array}{l}\text { · 透明度世界一 (1931 年の記録 }) \\
\text { ・布施明「霧の摩周湖」 }\end{array}$ & ・透明度の低下 & $\begin{array}{l}\text { ・マイイー規制 } \\
\text { ※無根拠とする批判。 } \\
\text { ・てしかがえこまち協議会 }\end{array}$ & $\begin{array}{l}\cdot \text { 山型 /1991 年 } \\
\cdot \text { 衰退期/ 中国における } \\
\text { 道東ブーム }\end{array}$ \\
\hline & $\begin{array}{l}\text { 森 } \\
\text { 林 }\end{array}$ & 屋久島 & $\begin{array}{l}\cdot \text { 縄文杉の発見 } \\
\cdot \text { 屋久島環境文化村構想 } \\
\cdot \text { 世界自然遺産登録 }\end{array}$ & $\begin{array}{l}\cdot \text { · し尿 /ゴミ問題 } \\
\text { ·屋久杉の根の踏み荒らし } \\
\text { ·猿 / 鹿害 }\end{array}$ & $\begin{array}{l}\cdot \text { · エコツーリズム/環境学習 } \\
\cdot \text { 利用調整 / デッキ等の整備 } \\
\text { ·各種登録 / 指定 / 募金 }\end{array}$ & $\begin{array}{l}\text { ・増加継結型 } / 2007 \text { 年 } \\
\cdot \text { 転換・過渡期 } \\
\text { ※现在の蔵少は一時的という見方 }\end{array}$ \\
\hline
\end{tabular}

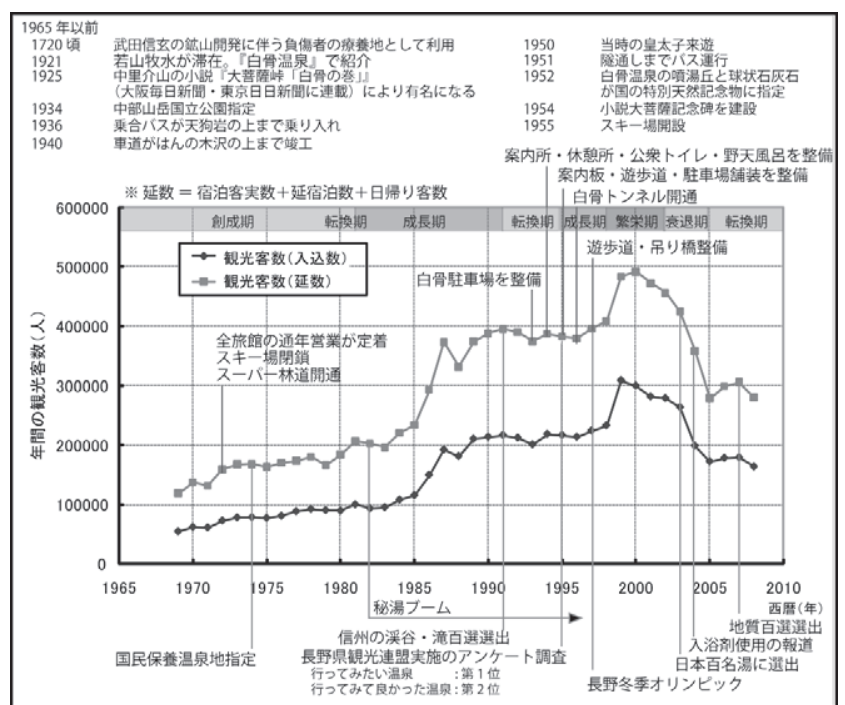

図 2 白骨温泉ブランドを取巻く出来事と観光客数の経年变化

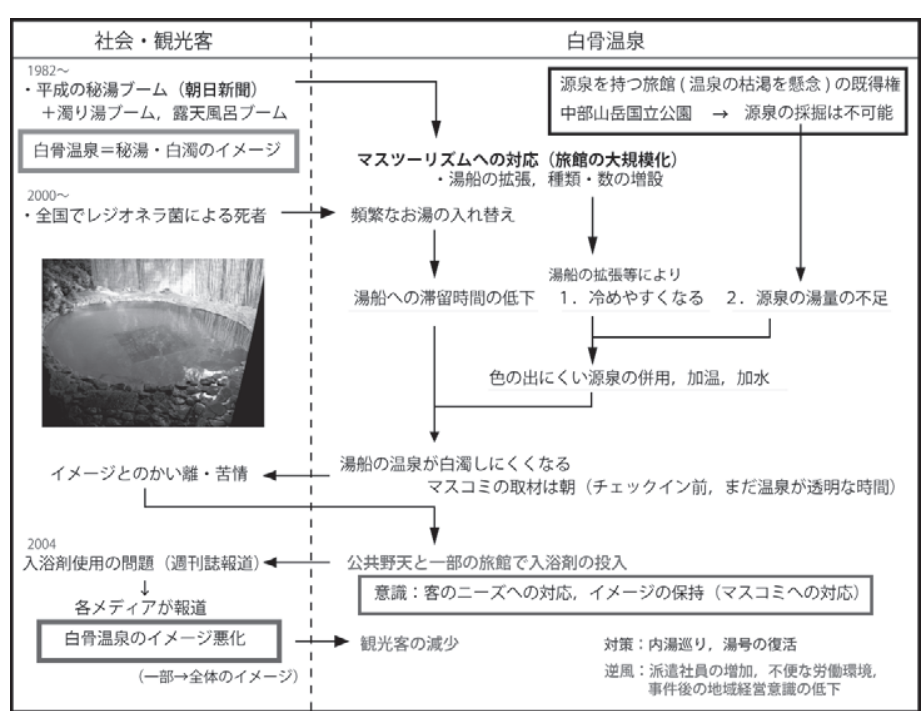

図 3 白骨温泉のイメージを変化させた要素とその相互関係
塩泉が沸いていることから秘湯と呼ばれる，源泉は透明で時間が経 過すると白濁する性質があり，白骨温泉のイメージを構築している.

本研究では, 松本市役所安曇支所観光課に対して史料や観光統計 等の提供を依頼した他, 2009 年 7 月に上述の全温泉施設及び土産屋, 案内所に訪問し，ヒアリング調查を実施した。

\section{（2）白骨温泉ブランドの変遷}

白骨温泉ブランドを取巻く出来事と観光客数の推移を図 2 に示寸. 白骨温泉は, 中里介山の小説『大菩薩峠「白骨の巻」』により, 広く 知られるようになった。 その後, 観光客数は交通基盤の整備や旅館 の通年営業化により徐々に増加していき, 80 年代前半からの秘湯ブ 一ムにより急増する，ブーム中は案内所や遊歩道など，白骨温泉内
の基盤整備が進んだ。しかしながら，景気後退等の影響から，2000 年を境に観光客数は減少に転じた。加えて, 2004 年 7 月には入浴剤 使用が発覚し，その傾向に拍車がかかった．以降，白骨温泉を訪れ る観光客数(入込数) は, 年間 19 万人弱で停滞し, 回復が遅れている.

\section{（３）白骨温泉のイメージ変容プロセス}

白骨温泉のイメージを変化させた社会的要素とその相互関係を, 図 3 にまとめた，全旅館へのヒアリング結果を総合すると，白濁で 有名な白骨温泉は, 朝日新聞発の秘湯ブームにより観光客が急増し た。しかし，白骨温泉は中部山岳国立公園に指定されており，また， 源泉の枯渇回避の観点から，新たな源泉採掘は不可能である。こう した事情の一方,ブームに対応する形で各旅館が湯船の拡張・増設を 
したことにより, 温泉の加水や他源泉の併用が必要になった. 湯船 の拡張は, お湯と空気との接触面が広くなることも意味しており, お湯が泠め易くなったことで, 加温も必要になった。また, 全国的 なレジオネラ菌対策を背景に, お湯の頻繁な入れ替えを余儀なくさ れ, 滞留時間が低下した. 温泉の(1)加水, (2)白濁の薄い源泉の併用, (3)加温, (4)滞留時間の低下, は温泉の白濁を薄くする原因となり, 観光客からの苦情が増えた. 加えて, マスコミの取材は旅館の営業 サイクルの関係上, 朝に集中するが, 朝はお湯を入れ替えた直後で あり, 湯船の温泉は透明である. 上記事情から, イメージ保持に苦 慮した公共野天と一部の旅館は入浴剤を入れるようになった。この 様子が週刊誌にて明るみとなり, メディアが報道した結果, 温泉の イメージが悪化し，白骨温泉は大きなダメージを受けた．白骨温泉 はオーバーユースによって提供できる資源の質が低下し，イメージ の悪化と観光客数の減少を招いた事例といえる.

なお，現在は入浴剤の使用は一切行っておらず，(1)内湯巡りの無 料化, (2)湯号の復活, (3)飲泉所の整備, (4)温泉粥の提供等により, 泉質の多様さを新たな資源として活用している. また, 都市部で PR 活動を行うなど白骨温泉ブランドの再興に向けた努力が続いている.

\section{3-3 屋久島}

\section{（1）屋久島の概要と調査方法}

屋久島は最高点が $1936 \mathrm{~m}$ (宮之浦岳 : 九州最高峰)であり, 日本最 南端の積雪地という地形から, 洋上のアルプスと呼ばれる.また, 雨量が多く「一ヶ月に 35 日雨が降る」と表現される。豊富な自然 が残り, 面積の $90 \%$ が森林, $40 \%$ が国立公園, $20 \%$ が世界自然遺 産である. 屋久杉に加え, 永田いなか浜 (ウミガメの産卵地), 白谷 雲水峡 (映画「もののけ姫」のモデル) など多様な資源が存在する.

本研究では, 屋久島町商工観光課に対して史料や観光統計等の提 供を依頼した他, 2010 年 12 月に屋久島観光協会事務局, 屋久島野 外活動総合センター他に訪問し，ヒアリング調查を実施した.

\section{（２）屋久島ブランドの変遷}

屋久島ブランドを取巻く出来事と観光客数の推移を図 4 に示す. 屋久島は 1950 年頃から小説に登場し, 天然記念物指定や名数選の 選出を受けた. 1964 年には霧島屋久国立公園に指定された。その後, 1989 年の高速船トッピーの就航により観光客が急増を始め, 1993 年の世界自然遺産登録を契機に, 名数選への選出, 映画やテレビド ラマの撮影·モデル, ラムサール条約登録など, 様々な形で注目を集 めた．高速船の值下げも重なり，観光客数は増加を続けた。

2008 年には高速船の值上げに伴い, 観光客数が減少に転じた. 翌 年も台風に伴う高速船の欠航や前年の NHK 大河ドラマ「篤姫」の 影響で, 観光客の目的地が指宿方面にシフトしたことが一因となり， 前年比約 5.8 万人の減少となった。 しかしながら, 島としてはこの 観光客の減少に対して大きな危機感はない. 反対に, 2009 年にミシ ユラングリーンガイドで三ツ星を獲得して以降, 外国人旅行客が増 加しており, 海外メディアへの露出増加に対する期待感が大きい.

世界遺産登録以降，屋久島世界遺産センター，屋久島環境文化村 センター, 屋久島うみがめ館等, 環境学習を目的とする施設の竣工 が目立つ. 自然環境を活用したエコッアーも数多く実施されている.

\section{（3）屋久島のイメージ変容プロセス}

屋久島のイメージを認知・強化させた社会的要素とその相互関係 を図 5 にまとめた。屋久島は元来林業により繁栄してきたが 50 年

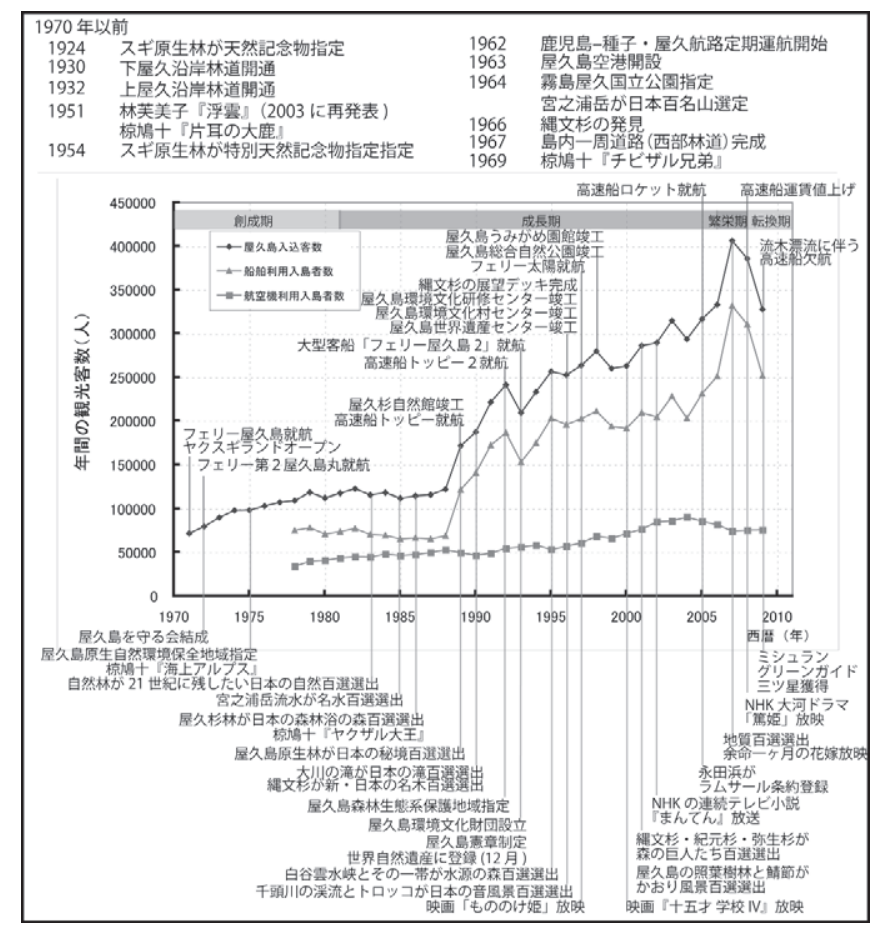

図 4 屋久島ブランドを取巻く出来事と観光客数の経年変化

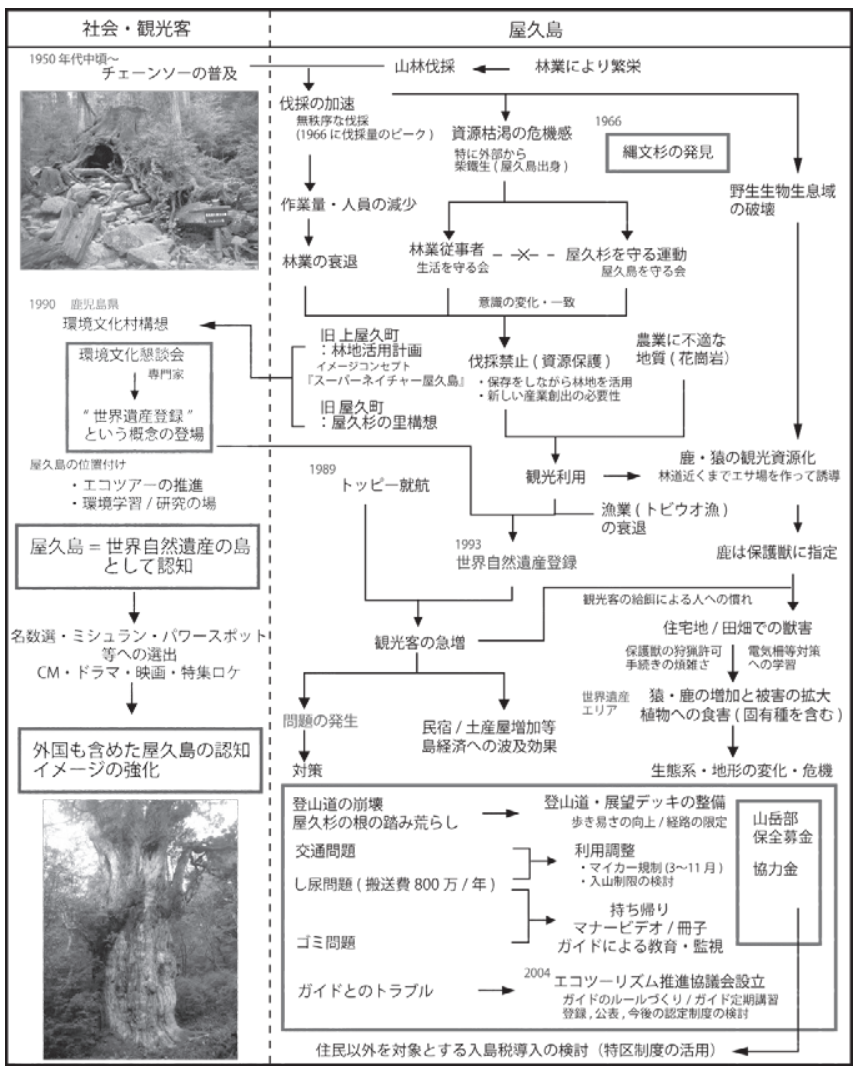

図 5 屋久島のイメージを峦化させた要素とその相互関係

代中頃からは, 伐採機器の進歩·普及により杉の伐採が加速した. 柴 鐵生氏の屋久杉保護運動の開始後も林業従事者との意見衝突が生じ たが，無秩序な伐採に伴い，次第に林業自体が衰退した。その結果， 杉の保護へと意見がまとまり，伐採禁止に至ると共に，農業に不適 な土壌(花崗岩)であることから, 林地の観光利用が模索された. 1990 年, 旧上屋久町は「林地活用計画」, 旧屋久町は「屋久杉の里構想」 




図 6 各観光地のブランドを取巻く出来事と観光客数の経年変化 
を策定した．鹿児島県は環境文化村構想を策定した．構想の準備主 体であった環境文化懇談会には, 研究者や専門家が在籍し “屋久島 の世界遺産登録”というテーマの共有が進み, 1993 年に屋久島は世 界自然遺産に登録され, 認知度が高まった。同時に高速船トッピー の就航によりアクセスが容易になったことや, シンボルとしての縄 文杉（1966 年発見）の訴求力も奏功し, 島の経済を潤した.

世界遺産の登録に伴う観光客の急増は，オーバーユースによる問 題を発生させたが，各種対策が実施されている，屋久杉の根の踏み 荒らしについては, 登山道や展望デッキを整備し, 縄文杉周辺は土 袞改良工を実施した。交通問題やし尿問題(処理能力以上の登山者 数)については, 荒川登山口までのマイカー規制(3-11月)を実施し, 入山規制も検討されている. ゴミ問題については, ガイドによる教 育·監視, マナービデオ・冊子の作成·配布を行った. ゴミの持ち帰り も定着した. 獣害については, 鹿と猿を観光利用のために誘導(餌場 を作成)した背景がある. 結果, 人に慣れ, 住宅地や田畑での獣害が 生じた. 電気柵, 看板, ネットの設置などの対策を講じているが, 動物の学習もあり, 解決には至っていない, 鹿は保護獣につき狩猟 手続きが煩雑であるため増加を続けている.世界遺産のエリアでは, 固有種を含む植生一の食害が生じ, 生態系や地形の変化が懸念され ている. 屋久島は, 冠ブランドの獲得が環境に影響を与えつつも, 観光客誘致に効果を発揮した事例といえる.

\section{3-4 観光客の増減が生じる要因}

研究対象とした他の 8 ケ所の観光地についても, ブランドを取巻 く出来事と観光客数の推移を図 6 に整理した注 ${ }^{3)}$. また, 以下に例と 共に示寸要因により観光客数に変化が生じることを確認した.

（1）気候的要因 : 気温，災害，天候の交通一の影響等

例：屋久島は 2009 年度の台風通過に伴い, 高速船の航路上に 大量の流木が漂流し， 久航したことで観光客数が減少した。

（2）基盤的要因：交通·施設の新設，料金改定等

例：白骨温泉における秘湯ブーム以降の観光客数の増加は, 林 道の開通による通年アクセスが前提といえる，屋久島では高速 船料金の変更に伴い観光客数が増減している.

（3）社会経済的要因 : 景気，ブーム，風評等

例：白骨温泉では秘湯ブームにより観光客数が増加し, 温泉偽 装問題後は偽装に無関係な旅館の宿泊者数も減少した.

（4）資源環境的要因：資源の質变化，新資源発掘，利用規制等 例：白骨温泉においては, 温泉の白濁が薄くなったことが, 結 果的に偽装問題を経て観光客数の減少に繋がった。一方, 二セ コ山系では, 観光カリスマに選定されているロス・フィンドレー 氏がラフティングを広めたことで, 1999 年を境に夏期の観光客 数が冬季の観光客数を上回るようになった.

(5) ブランド的要因 :

a）名数選選出, 世界遺産登録, 国立公園指定, 文化財登録等 による「冠」ブランドの獲得

b) テレビドラマ, 映画, ニュース, 地域活動, イベント, 歴 史等による「注目」ブランドの獲得

例: 屋久島では世界遺産登録以降, 観光客数が増加した.また, 付随して名選数への選出, 映画やテレビのロケ等が相次ぎ, 海 外も含めて屋久島の認知度は向上している.

また，ケーススタディの観光地では観光振興が続くと資源の破壊
や枯渇が生じ，放置すると観光地として衰退するため，持続可能な 循環構築に向け, 環境保護施策や市民活動等の対応が見られるが, そうした観光地におけるブランディング, 観光振興, 環境破壊, 対 策・取組みの相互関係は図 7 に示すように整理できる.

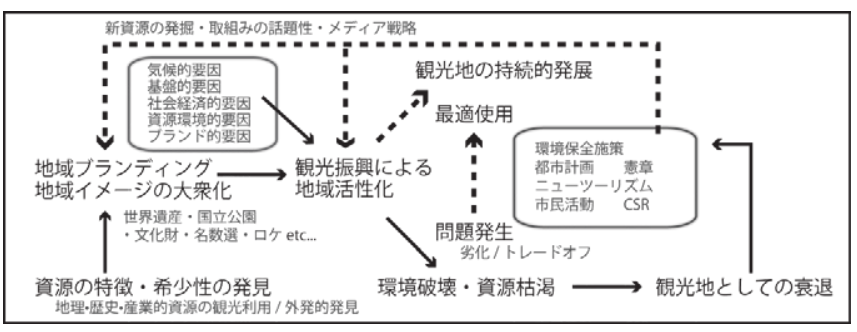

図 7 観光地のイメージ形成を取巻く要素と相互関係

\section{4. 観光地におけるブランディングプロセスの比較}

4-1 観光地における資源問題·危機とその対策手法

ケーススタディの観光地が抱える問題は以下の 3 タイプに分類で き，その問題に応じた形で各種対策が出現している.

（1）断続的問題：観光地として成立する以前から今日に至るまで断 続的に存在していた問題.

例えば，柳川の堀割の水質污濁，摩周湖の透明度の低下，鳥取砂 丘の雑草の繁茂等が挙げられる。断続的な問題の場合，原因の解明 が必要になる，鳥取砂丘では環境省の調查により，草原化の原因が 植林による砂の動きの低下と河川護岸による砂の供給量の減少にあ ることを特定した。これに基づき，環境省は国立公園の特別保護地 区内の除草作業に許可を出し, 植林地の伐採も進んだ。除草作業は 市民活動や企業のCSR として実施される.

（2）突発的問題：偶発的な事故，あるいは突然浮上した開発計画等 によって生じる問題.

例えば, 柳川の堀割埋立ての動き, 尾瀬のダム問題·道路建設問題, 琴引浜の重油流出事故・リゾート開発計画・廃棄物漂着等が挙げられ る. 突発的な問題に対しては, 市民活動·啓蒙活動によって環境を改 善したり，開発計画を回避してきた。こうした活動はメディアの関 心を集め，それ自体が観光地の注目ブランドになることもある。琴 引浜では,「琴引浜の鳴り砂を守る会」が中心となってリゾート計画 の回避や砂浜の美化(ごみ収集イベントの開催や禁煙ビーチ化の実 現) に努めてきた. 特にナホトカ号事故の際の重油回収活動は大きく 報道され，琴引浜や鳴き砂の認知も高まった．

（3）オーバーユース問題 : 観光資源のオーバーユース，または観光 客の需要を満たそうとする中で生じる問題 例えば，白骨温泉の白濁の薄化·入浴剂使用，二セコの乱開発，伊 香保温泉の温泉表示問題 (温泉の利権), 尾瀬の踏み荒らし·裸地化, 屋久島の踏み荒らし・し尿問題・ごみ問題・ガイド問題等が挙げられ る。オーバーユースにより生じる問題に対しては，(1)自主規制，(2) 環境施設整備，(3)エコツーリズムによる解決が見られた。ニセコ山 系(俱知安町とニセコ町)は不動産投資の過熱に対応して準都市計画 区域を指定した。また，白骨温泉や伊香保温泉では，使用する源泉 の量を決め, 当該源泉の採掘量を一定に保っている，尾瀬では電力 事業者の CSR として複線木道の敷設やエコトイレが整備されてき たが, CSR の様子はテレビ CM でも放送され, 尾瀬の認知やブラン ド強化にも繫がったと言える．観光地の場合は社会の関心も高く， 
表 3 観光資源に生じる劣化とトレードオフの分類

\begin{tabular}{|c|c|c|c|c|c|c|}
\hline \multirow{2}{*}{ 観光客の } & \multicolumn{2}{|c|}{ 断続的問題 } & \multicolumn{2}{|c|}{ 突発的問題 } & \multicolumn{2}{|c|}{ オーバーユース問題 } \\
\hline & 事象と懸念される影響 & 具体的事例·対応 & 事象と懸念される影響 & 具体的事例-対応 & 事象と獎念される影響 & 具体的事例-対応 \\
\hline 気象的要因 & $\begin{array}{l}\text { 温暖华·地震 } \\
\text { 资源の劣化 } \\
\text { (因果関係は不明) } \\
\text { 観光客の減少 } \\
\text { [劣化の発生] } \\
\end{array}$ & 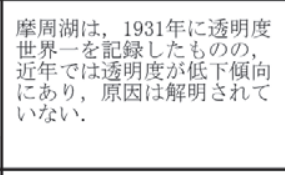 & $\begin{array}{c}\text { 台風·地震 } \\
\text { 䚇光客の隇少 } \\
\text { 経済的利益と資源管理 } \\
\text { 機能の低下 } \\
\text { 【劣化の発生】 } \\
\end{array}$ & 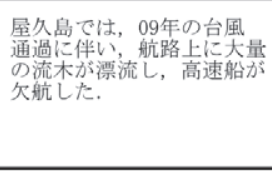 & - & - \\
\hline \multirow[b]{2}{*}{ 基盤的要因 } & \multirow[t]{2}{*}{ 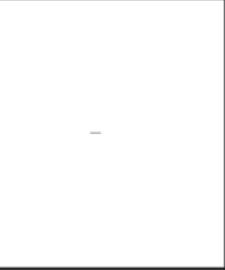 } & \multirow[b]{2}{*}{-} & \multirow{2}{*}{ 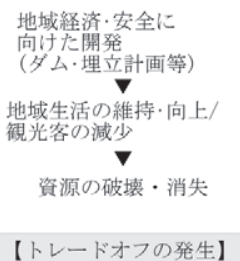 } & 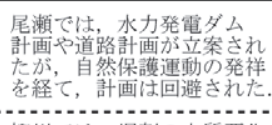 & \multirow{2}{*}{ 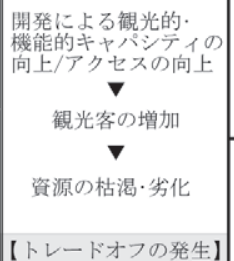 } & 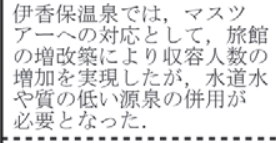 \\
\hline & & & & 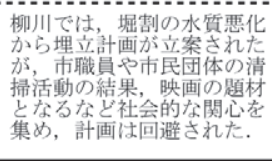 & & 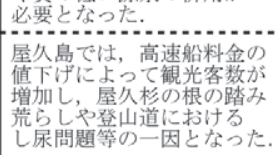 \\
\hline \multirow[b]{2}{*}{ 社会経済的要因 } & $\begin{array}{l}\text { 地域生活の影響 } \\
\text { 资源の劣化 }\end{array}$ & \multirow{2}{*}{ 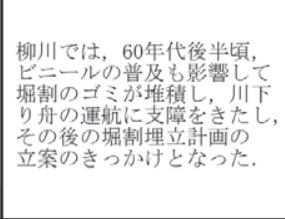 } & 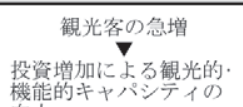 & \multirow{2}{*}{ 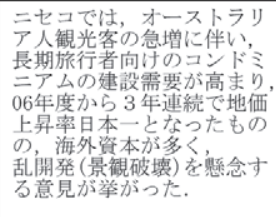 } & \multirow{2}{*}{$\begin{array}{c}\text { プームや好影気 } \\
\text { 観光客の增加 } \\
\text { 資源の枯渴·劣化 }\end{array}$} & 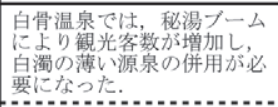 \\
\hline & 観光客の減少 & & $\begin{array}{l}\text { 向上 } \\
\text { 乱開発等に伴う资源の } \\
\text { 劣化·等囲気の変化 } \\
\text { 【トレードオフの発生】 }\end{array}$ & & & 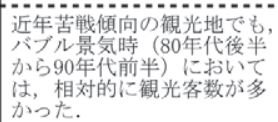 \\
\hline \multirow{3}{*}{ 資源環境的要因 } & \multirow{3}{*}{ 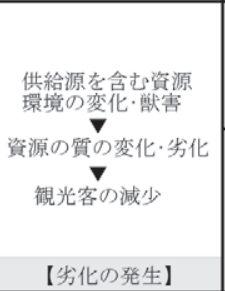 } & \multirow{3}{*}{ 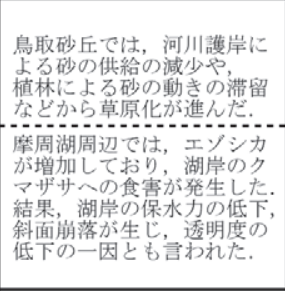 } & $\begin{array}{l}\text { 事故や災害による } \\
\text { 資源偅 }\end{array}$ & \multirow{3}{*}{ 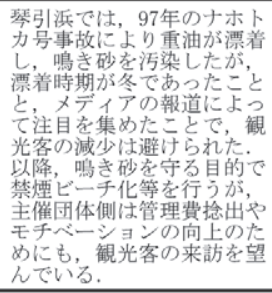 } & \multirow{3}{*}{ 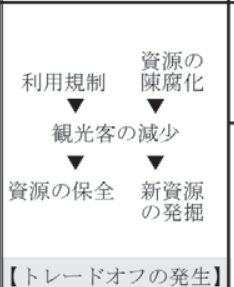 } & 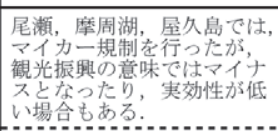 \\
\hline & & & $\begin{array}{c}\text { 観光客の減少 } \\
\text { 経済的利益哏 } \\
\text { 資源管理機能の低下 }\end{array}$ & & & 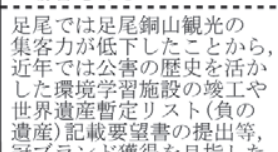 \\
\hline & & & 【劣化の発生】 & & & \\
\hline \multirow{4}{*}{ ブランド的要因 } & \multirow{4}{*}{ 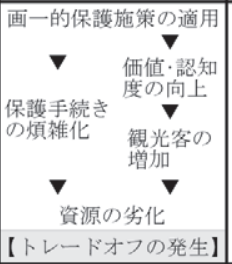 } & \multirow{4}{*}{ 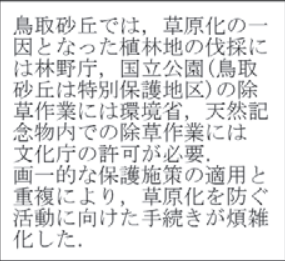 } & $\begin{array}{c}\text { 報道等に上るる } \\
\text { 認知度の向上 } \\
\text { 资源に対するマイナス }\end{array}$ & \multirow[t]{4}{*}{ 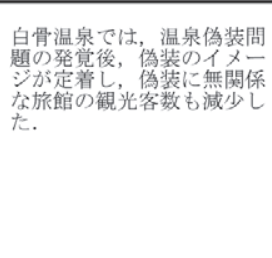 } & \multirow{4}{*}{ 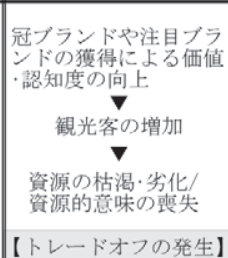 } & 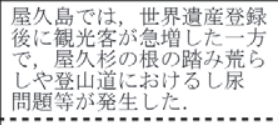 \\
\hline & & & 観光客の減少 & & & 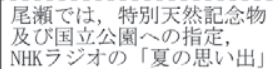 \\
\hline & & & & & & 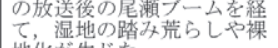 \\
\hline & & & & & & \\
\hline
\end{tabular}

観光地の環境保全と CSR との相性は良い。また, 屋久島ではエコ ツーリズムの積極的な導入により, 観光振興と同時に観光客のマナ 一向上や環境保全に成功したと言える.

以上の観光客の増減要因と観光地における資源問題・危機から, 資 源の破壊と観光客の減少の両方を招く事象を「劣化」, 資源の保全と 観光客の増加のいずれかを実現する一方で他方との両立が難しくな る事象を「トレードオフ」と捉え, 観光地の資源に生じる劣化とト レードオフについて表 3 に整理した.

断続的問題では, 自然現象や地域生活の影響が資源を劣化させ, 観光振興の妨げとなる事例や, 冠ブランドの獲得を狙った結果, 保 護施策の重複適用によって観光客への訴求力を得る一方で，資源の 保護手続きが煩雑化するというトレードオフに陥る事例が見られる. 突発的問題では, 災害や事故によって資源が劣化·破壊され, 観光に も影響をもたらす事例や, 急激な投資増加や地域の経済振興·安全対 策と資源の保全がトレードオフに陥る事例が多い。オーバーユース 問題については各種要因によって観光客数が増加し, 資源のキャパ シティを超えることで問題を招き，トレードオフに陥る.

現状, 観光地としても資源の劣化を防ぐために, 表 1 に挙げた環 境施策を講じるが, その環境施策が冠ブランド向上と更なる観光振 興, もしくは資源の保全機能向上のいずれかに偏重することで, 観 光振興と資源保全のトレードオフに至る. 寸なわち, 観光地が単発
の環境施策を講じるだけでは, 劣化の回避は可能でも同時にトレー ドオフが生じ, 別の問題が発生する構図となるため, 当該観光地に 対する持続可能性の付与には至らないものと考えられる.

\section{4-2 観光地のイメージ形成と資源保全プロセス}

外部からのアクセスを可能にする交通基盤は，観光地の創成期の 間に整備を終える。また，成長期から最盛期までの間は，大都市圈 からの基幹交通が整備されるとともに，観光地内部の施設（スキー 場, テーマパーク，公共浴場，宿泊施設等）が次々に整備され，観 光地としてのキャパシティが上昇していく. 遊歩道等の基盤整備も この時期に進む. 衰退期以降は, 社会基盤の整備はほとんど見られ ず，環境·文化をテーマにした情報施設の竣工が目立つ。

観光地の冠ブランドとなる環境施策 (国立公園, 文化財, 世界遺 産，ラムサール条約等）の適用を受ける場合，その資源の価值を法 的に認め内外に示寸効果がある注 4).このため, 厳重な環境保全対策 が実施される一方, 集客効果・ブランディング効果も非常に高いとい う側面がある.観光地のイメージを形成·強化するような冠ブランド の獲得は観光地の創成期である場合が多いが，近年も世界遺産登録 や名数選等の冠ブランドが出現している.また，景観関連の保護， 地域連携施策が積極的に施行されている. 冠ブランドの獲得後は, その価值を保護・補強するための計画·事業·条例等が施行される.

一方, 注目ブランドの獲得は観光地の時期区分に関係なく出現寸 
る. 中には, テレビの普及以前にラジオや文学作品によって観光地 のイメージが構築·認知され, 現在でも受け継がれているものもある. 近年ではインターネットのロコミや, 企業の CSR, 新資源の発掘に よって観光地の資源の認知が進むケースもある.

\section{4-3 観光地における冠ブランドの強化プロセス}

ケーススタディを通じて見られる傾向として, 観光地はブランド 化に際し, (1)環境施策の範囲の拡大もしくは独立化, (2)重要エリア の追加的な保護指定, (3)他施策によるブランド補強, を繰り返す点 が指摘できる.また, 冠ブランドの強化·重複は保護の強化を意味す るが，世界遺産登録等の国際的施策へのステップとしての側面が強 く, 最終的には観光振興が目的となる. 但しその結果, 複数の異な る管理主体による管理が複雑化し, 本来の指定や登録の主旨が損な われ，相互関係の中での管理がかえって難しくなる場合もある.

例えば屋久島では, 1964 年に霧島国立公園に追加編入する形で国 立公園の冠を得た. その後, 原生自然環境保全地域指定等による環 境保全策の強化と区域の拡張が行われ, 1993 年に世界自然遺産, 2005 年にラムサール条約に登録された. その効果を近隣にも派生さ せ, 観光振興を狙う目的で, 口永良部島も霧島屋久国立公園に編入
した. 2012 年には霧島・錦江湾地域と屋久島地域が個別の国立公園 に独立したが，独立は冠の向上という意味で悲願とされていた注 ${ }^{5)}$.

一方, 鳥取砂丘では, 植林や河川護岸に伴う草原化が問題となっ ているが, 植林地の伐採には林野庁, 国立公園(鳥取砂丘は特別保護 地区)の除草作業には環境省, 天然記念物内での除草作業には文化庁 の許可が必要となる．草原化を防ごうとする活動が盛んであること を鑑みると, 鳥取砂丘における環境保全とは, 自然をありのまま放 置することではなく, 人為的な影響による景観変化を防ぐことを指 すが, 各省庁の所管する環境施策とその重複適用が地元側の環境保 全活動に向けた手続きを複雑化している状況にある.

上記ケーススタディから得られた観光地のイメージ形成と資源保 全のプロセスは一般的なモデルとして図 8 のようにまとめることが できる．冠ブランドや注目ブランドの獲得は資源の認知やイメージ 付与の契機となる. 創成期ではブーム, テレビ, ラジオ, 伝説・文学, 楽曲, 国立公園·文化財指定等が多かったが, 近年では世界遺産登録, 環境学習, CSR, 市民活動等へと変化してきた。映画のように時期 区分に関係なくイメージ形成に寄与寸るものもある。一方，事故や 資源の質変化によりマイナスイメージが付与されることもある.

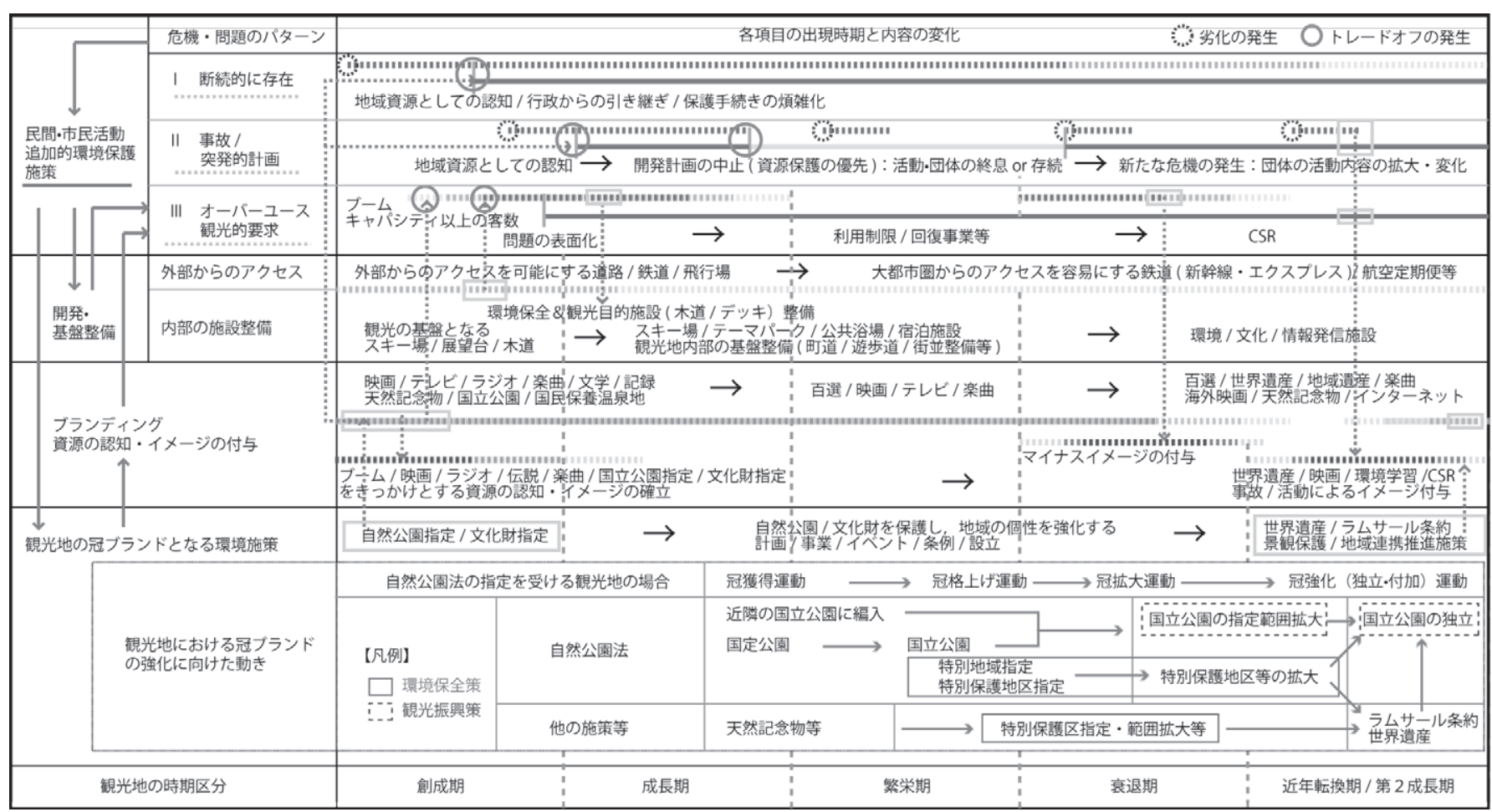

図 8 観光地のイメージ形成·保全プロセス

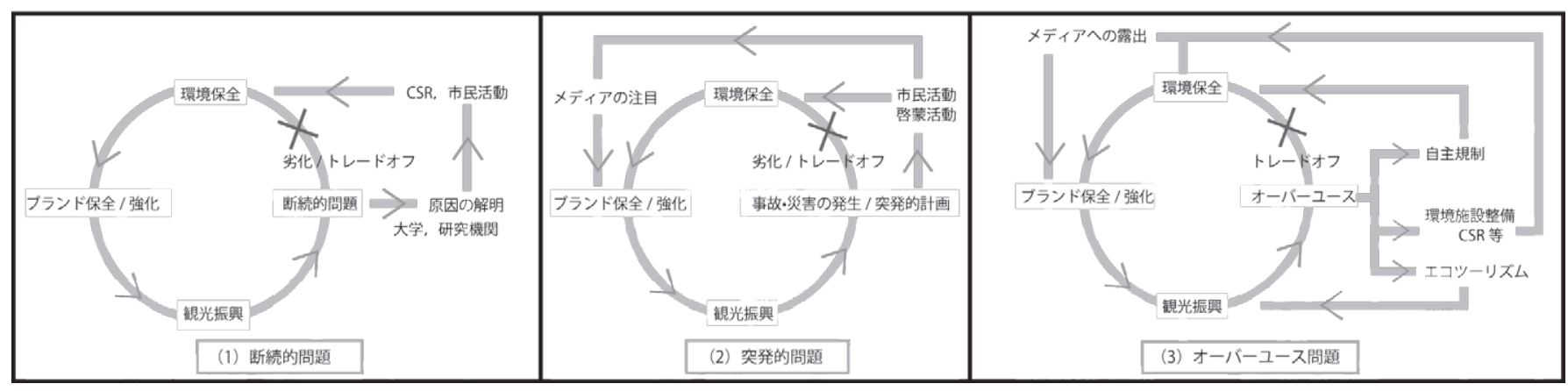

図 9 観光地における持続的資源利用策 


\section{4-4 観光地における持続的資源利用策}

観光地が直面する資源的問題については, 先進事例の教訓を活か し, 問題の発生を前提として, 持続可能な資源利用循環を再構築し ていく必要があるが, ケーススタディで得られた対応策を踏まえ, 上述の 3 つの問題のタイプに応じた持続的な資源利用策を図 9 に示 すモデルとして整理した. 観光地において導入された環境施策が, 資源ブランドの保全·強化に繋がり, 観光客誘致に貢献する以上, 従 来どおりの環境施策を繰り返す方法では，資源環境の保護や持続的 利用という観点からは不足する。従って, 発生もしくは発生が予想 される問題への追加対策を併せて講じることで, 観光地における環 境保護機能を補完し, 永続的な資源利用循環を構築していく意識が 重要と言える。資源の価值の証明に繋がる環境施策とそこで生じる 問題への対策という二段構えの環境対策こそが, 観光地における持 続可能なブランディングの方法として考えられる.

また, 観光地の陳腐化を防ぎ, 発展を続けるためには, 循環を保 持した上で利益の最大化を目指寸一方, 資源の更新・補強が必要にな る. ニセコのラフティングや屋久島のエコッアーのように, 資源の 新たな価值の発見·活用を進めると共に, 新たな資源利用循環を構築 していくことが重要であると言える.

\section{5. おわりに}

\section{5-1 冠ブランドを契機とする資源保護プロセスの課題}

観光地における資源の保護については，これまで主として自然公 園法や文化財保護法の適用対象とすることにより進めてきたが，国 あるいは国際的な環境施策の指定·認定は, 資源と地域の価值の裏付 けを得ることにも繋がる，このため, 自治体は積極的に資源を保護 の対象にしている側面もあり，こうした冠ブランドは年代によって 種類を変化させつつも, 現在は乱立傾向にある，画一的な法律によ る保護は, 個別の資源特性に対応できず, オーバーユースや形骸化 など新たな問題を発生させることもケーススタディでは見られた. 現行施策の保護の対象となることで, 指定エリア内は厳しく制限さ れ保護されるが，その周囲は無秩序に開発が進む場合も多く, 観光 客が増えることで, 保護指定エリア自身が観光地のシンボルへと変 化していく. 即ち, 現行施策による保護は形式上の保護であり, 自 然資源に対して人の関与を制御したり，文化的な資源の俗化を防ぐ という意味における保護ではなくなってしまうことも少なくない.

\section{5-2 持続可能なブランディング方策の課題}

今後は環境·ブランド·観光の相互関係を意識し, 供給源, 生態系, 観光·交流等, 資源を取巻くあらゆる要素の循環構造を把握した上で, 適用する保護施策を選択・立案すべきであると言える. 加えて, 資源 の形·質·意味を一体的に保全する柔軟かつダイナミックな施策を講 じることで, 永続的な循環に代えていく必要があるが, 今後の観光 地ブランディングにおいては, 図 8 に示したプロセスに留意し, 図 9 で提示したような資源利用循環のモデルを積み重ねていく意識こ そが,資源を守りつつ繁栄を目指寸上での基礎になるものと考える.

\section{注}

注 1）観光客数の増減状況から, 観光地の時期区分を創成期, 成長期, 繁栄 期，衰退期，転換・過渡期と定義した。

注 2) 2011 年 1 月時点.

注 3) 各観光地のブランドを取巻く出来事と観光客数の経年変化(図 $2 \cdot 4 \cdot 6$ )
については, 参考文献に記載した史料·論文等に加え, 各自治体から年表や 観光統計データ等の資料提供を受け，著者が編集・作成した.

注 4) 屋久島 (屋久島観光協会事務局) 及び鳥取砂丘 (環境省 浦富自然保護官 事務所)へのヒアリングより.

注 5）屋久島 (屋久島観光協会事務局) へのヒアリングより.

\section{参考文献}

1）国土交通省観光庁編：観光白書 平成 22 年度版, 2010

2）バレーン· $L \cdot$ スミス編，三村浩史訳 : 観光・リゾート開発の人類学-ホスト \&ゲスト論でみる地域文化の対応, 勁草書房, 1991

3）西村幸夫編 : 観光まちづくりーまち自慢からはじまる地域マネジメント, 学芸出版社, 2009

4）石森秀三 : 内発的観光開発と自律的観光，ヘリテージ・ッーリズムの総合 的研究，国立民俗学博物館，pp.5-19，2001

5）川原晋, 古川尚涁 : 東アジアの歴史的都市が持つ生態学的特徴を資源とし た社会基盤整備と観光のあり方, 第 13 回観光に関する研究論文集, 財団法 人アジア太平洋観光交流センター, pp.55-56, 2007

6）山口しのぶ：世界文化遺産地域における持続可能な開発に関する研究，文 化遺産マネジメントとツーリズムの持続可能な関係構築に関する研究，国 立民俗学博物館, pp.153-165，2006

7）西山徳明,池ノ上真一: 地域社会による文化遺産マネジメントの可能性 竹 富島における遺産管理型 NPOの取り組み, 文化遺産マネジメントとツーリ ズムの現状と課題, 国立民俗学博物館, pp.53-75，2004

8）敷田麻実：観光による持続可能な地域資源の活用戦略，2010

9）海津ゆりえ，真板昭夫：西表島におけるエコツーリズムの発展過程の史的 考察, エコツーリズムの総合的研究, 国立民族学博物館, pp.211-239, 2001

10）小林英俊：自然遺産管理とツーリズムが共存する仕組み，文化遺産マネ ジメントとツーリズムの持続可能な関係構築に関する研究, 国立民俗学博 物館, pp.167-197，2006

11）山村高淑，張天新，藤木庸介：世界遺産と地域振興 中国雲南省·麗江に くらす，世界思想社， 2007

12）西山徳明：ヘリテージ・ッーリズムと歴史的環境の保全 世界遺産白川村 合掌集落における自律的観光の実現と課題, ヘリテージ・ツーリズムの総合 的研究，国立民俗学博物館，pp.61-80，2001

13）山中速人：イメージの<楽園 > 観光八ワイの文化史, 筑摩書房, 1992 14）山崎隆之, 菅裕紀, 津々見崇, 十代田朗 : 近接する競合観光地における イメージ形成プロセスの比較研究 -別府・湯布院・黒川温泉を事例として一, 第 25 回日本観光研究学会全国大会学術論文集, pp.265-268, 2010

15）日外アソシエーツ株式会社編：事典・日本の観光資源一○○選と呼ばれる 名所 15000,2008

16）安曇村誌編纂委員会編 : 安曇村誌, 1998

17）鵜飼克郎：ウソの温泉 ホントの温泉，小学館， 2005

18）柳川市観光協会 : 水と光につつまれて 50 年のあゆみ, 2004

19）鬼塚義弘：二セコ地域への外国人観光客急増とその理由一世界のリゾート と競争するために-，季刊 国際貿易と投資 No.63，pp.114-125，2006

20）橴川市：渋川市観光基本計画，2009

21）敷田麻実 : 観光地域における非営利・営利組織のガバナンスと恊働モデ ルに関する研究-北海道弟子屈町の事例分析から-, 日本地域政策研究第 8 号, pp.73-80, 2010

22）尾瀬林業株式会社：はるかな尾瀬を永遠に一尾瀬を守り、育み，伝える 一，尾瀬国立公園記念事業実行委員会，2008

23）秋山智英 : 森よ、よみがえれ 足尾銅山の教訓と緑化作戦, 農文協, 1990 24）松田真由美：鳥取砂丘観光の課題と方向性-砂丘政策の歴史的分析から, 2004

25）敷田麻実，末永聡：地域の沿岸域管理を実現するためのモデルに関する 研究 : 京都府網野町琴引浜のケーススタディからの提案, 日本沿岸域学会 論文集，pp25-36，2003

26）坂井宏光：日本の世界遺産における環境保全型観光産業の発展と課題一 屋久島の世界自然遺産を中心として一, 九州国際大学 教養研究第 15 巻第 1 号, pp.63-79, 2008

27）加藤則芳：日本の国立公園，平凡社， 2000

28）岩井正 : 伝建地区（伝統的建造物群保存地区）の現状と課題一伝建地区全 国アンケートからみたまちづくりのサスティナビリティー, 2007

29）土田夢子, 十代田朗, 津々見崇 : 町並夕観光地の発展過程と観光振興及 び町並み保全をめぐる意見の関係に関する研究-倉敷·美観地区を対象とし て-，都市計画論文集 NO.43-3，pp.601-606，2008 


\title{
COMPARISON STUDY ON PROCESS OF FORMING BRAND IMAGE AND PRESERVATION
} OF REGIONAL RESOURCES IN TOURIST AREAS

\author{
Yuya MARUGAMI* and Atsushi DEGUCHI** \\ * Mitsui Fudosan Co., Ltd., M. Env. \\ ** Prof., Graduate School of Frontier Sciences, The Univ. of Tokyo, Dr. Eng.
}

Tourism is expected to vitalize the declined region's economy and to create the region's brand, but it sometimes causes the problems such as the pollution and the disruption of natural resources. This study aims to clarify the treating process of the problems caused by the tourism boom through the ten case studies chosen by authors, and to suggest how to improve the development process of tourism areas from the view of sustainable development based on analysis of the treating ways in each case. The objectives of this study are as follows;

1) To clarify how the tourist areas resulted in suffering the severe environmental problems or the destruction of natural environment through analysis on the process of producing the brand image and preserving the regional resources in the cases.

2) To clarify the process from the problem occurring and the result of solution in the tourist sites through analysis on the changing process of cases which had been confronted with the environmental crisis such as pollution or destruction of the natural resources.

3) To show a model of the sustainable development process and method for building the brand as the popular tourist site through the comparison study of cases.

As a result, the measure specified by the subject more than a country such as the national park registration is effective in accepting worth of the resources. For this reason, while severe environmental preservation measures are implemented, a draw and the branding effect are also high. Acquisition of a brand which forms and strengthens the image of a tourist resort is the initial stage of a tourist resort in many cases. And brands, such as world heritage registration, have appeared also in recent years. In recent years, there is also a case where the cognition of the resources of a tourist resort progresses by the excavation of the word-of-mouth communication of the Internet, CSR of a company and the excavation of new resources. On the other hand, a minus image may be given by accident and change of the quality of resources. In addition, the tourist resort which obtained the brand by environmental measure repeats 1)Expansion of the range of an environmental measure, or independentizing, 2)Additional protection specification of important area, for strengthening of a brand, 3)Brand reinforcement by other measures. If the subject of an environmental measure becomes plurality, management of resources may become rather difficult. Moreover, the problem which a tourist resort has can be classified into the following three kinds.

1) A continuous problem: The elucidation of the cause by a research institute is needed for solution.

2) A sudden problem: Civic activities and an educational campaign perform improvement of environment and evasion of development for solution.

3) The problem by overuse : Self-imposed control, environmental institution maintenance, and eco-tourism are performed for solution.

As a conclusion, it suggests the importance that the local society of tourist areas should consider the process including the recycling use of regional resources together with the promotion for sight-seeing in order to make the balance of vitalization of tourism and preservation of natural resources. 